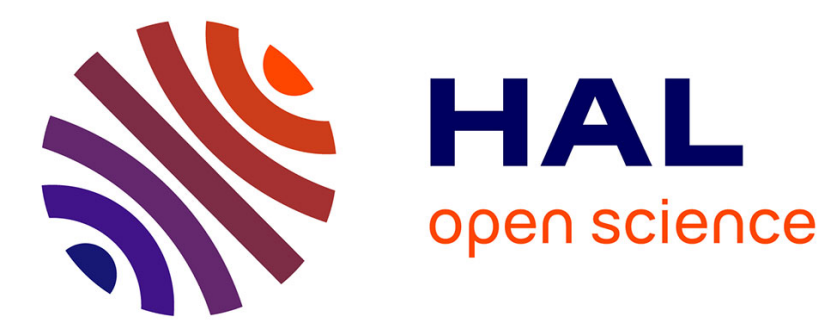

\title{
The Chromosomes of Lepturinae (Coleoptera: Cerambycidae) II. A study of eight more species, with focus on Desmocerus palliatus
}

\author{
Anne-Marie Dutrillaux, Bernard Dutrillaux
}

\section{- To cite this version:}

Anne-Marie Dutrillaux, Bernard Dutrillaux. The Chromosomes of Lepturinae (Coleoptera: Cerambycidae) II. A study of eight more species, with focus on Desmocerus palliatus. Annales de la Société Entomologique de France, 2019, 55 (4), pp.348-354. 10.1080/00379271.2019.1637779 . mnhn-02365491

\section{HAL Id: mnhn-02365491}

\section{https://hal-mnhn.archives-ouvertes.fr/mnhn-02365491}

Submitted on 15 Nov 2019

HAL is a multi-disciplinary open access archive for the deposit and dissemination of scientific research documents, whether they are published or not. The documents may come from teaching and research institutions in France or abroad, or from public or private research centers.
L'archive ouverte pluridisciplinaire HAL, est destinée au dépôt et à la diffusion de documents scientifiques de niveau recherche, publiés ou non, émanant des établissements d'enseignement et de recherche français ou étrangers, des laboratoires publics ou privés. 
The Chromosomes of Lepturinae (Coleoptera: Cerambycidae) II. A study of 8 more species, with focus on Desmocerus palliatus

Anne-Marie Dutrillaux, Bernard Dutrillaux (a)

Institut de Systématique, Evolution, Biodiversité (ISYEB) Muséum National d'Histoire Naturelle, CNRS, Sorbonne Université, EPHE, CP39, 57 rue Cuvier 75005 Paris France

(a) Corresponding author. Email: bdutrill@mnhn.fr

Summary. Following the study of 28 species of Lepturinae (Coleoptera:

Cerambycidae) the karyotypes of 7 additional Palaearctic and one Nearctic species are established. The 19,X male karyotypes found in genera Stictoleptura (4 species), Vadonia and Judolia (1 species each) confirm the loss of $Y$ chromosome in Lepturini. The 22,XY male karyotype of Cortodera humeralis is very close to that of some species of Rhagiini (genera Gaurotes, Acmaeops, Dinoptera, all 22,XY) and Grammoptera ruficornis $(24, \mathrm{XY})$ recently reported. We propose that these taxa form a monophyletic group within Rhagiini. The karyotype of the Nearctic species Desmocerus palliatus $(23$, neoXneoXneoY) is quite different and characterized by the presence of many acrocentric chromosomes and and a complex autosomegonosome translocation. Its particular karyotype is compatible with its present classification within a separate tribe, the Desmocerini.

Résumé. Après l'analyse des chromosomes de 28 espèces de Lepturinae (Coleoptera: Cerambycidae), les caryotypes mâles de 7 autres espèces paléarctiques et d'une espèce néarctique sont présentés. Les caryotypes 19,X observés dans les genres Stictoleptura (4 espèces), Vadonia et Judolia (1 espèce de chaque) confirment la perte du chromosome $Y$ chez les Lepturini. Le caryotype mâle 22,XY de Cortodera humeralis le rapproche de celui des genres Gaurotes, Acmaeops et Dinoptera, tous également à 22,XY et de celui de Grammoptera ruficornis $24, \mathrm{XY}$ récemment rapportés. Ces données indiquent qu'ils forment un groupe monophylétique, probablement dérivé d'ancêtres de Rhagiini, à caryotype 20,XY. Enfin, le caryotype de l'espèce néarctique Desmocerus palliatus (23,neoXneoXneoY) est très différent et caractérisé par la présence de nombreux chromosomes acrocentriques et d'une translocation complexe autosomegonosome d'un type rarement observé. Ce caryotype original est compatible avec sa classification actuelle dans une tribu séparée, les Desmocerini. 
Keywords: Lepturinae; chromosomes; classification; Cortodera; Desmocerus

Lepturinae are composed of about 1,000 identified species, largely distributed over the world, principally in the Northern hemisphere. Their systematic nomenclature and classification remain uncertain and moving. A given species may be alternatively classified into a large variety of genera such as Leptura Linnaeus, 1758, Corymbia Hill \& Jonhson, 1995, Paracorymbia Miroshnikov, 1998, Brachyleptura Casey, 1913, Aredolpona Nakane and Ohbayashi, 1957, Rutpela Nakane \& Ohbayashi, 1957, Stictoleptura Casey, 1927, Anastrangalia Casey, 1924, Strangalia Audinet-Serville, 1835 etc..., depending on the importance given to such or such morphological character. The imbroglio is not less for the classification into tribes. Their number varies from 5 to 8 , and only the existence of Lepturini Latreille, 1802, Rhagiini Kirby, 1837, Desmocerini, Blanchard, 1845, Encyclopini, LeComte, 1873 and Xylosteini Reitter, 1913 makes consensus, although there is no complete agreement on the species which composed them. Lepturini and Rhagiini are by far the two most numerous tribes, in which some genera such as Cortodera Mulsant, 1864 and Grammoptera Audinet-Serville, 1835 have been alternatively classified. Recently, the chromosome study of males from 28 species of Lepturinae revealed a mixture of $X Y$ and $X O$ sex formulae (Dutrillaux \& Dutrillaux, 2018). Almost all species from the other sub-families of Cerambycidae have an XY formula (Smith \& Virkki, 1978), which means that the $Y$ chromosome was lost in a group of Lepturinae. Such transmissible chromosome change is hardly reversible and must have a strong systematic value. All XO males studied belonged to Lepturini, while XY males were found in various tribes. It was concluded that the loss of $Y$ chromosome might be a synapomorphy of the tribe Lepturini (Dutrillaux \& Dutrillaux, 2018), but one species, Grammoptera ruficornis Fabricius, 1781, presently classified in Lepturini (Lobl \& Smetana, 2010) made exception with its $X Y$ sex chromosomes. Here, we report chromosome data of 8 more species of Lepturinae, including Desmocerus palliatus Forster, 1771, which belong to Desmocerini, a tribe never studied cytogenetically. It is shown that Cortodera humeralis shares many chromosomal similarities, including its $\mathrm{XY}$ sex formula, with a group of species usually classified into Rhagiini and G. ruficornis, usually classified into Lepturini. This provides a strong objective argument to challenge the classification of both genera Grammoptera and Cortodera into Lepturini. On the basis of their chromosome constitution, we propose that they 
form a monophyletic group within Rhagiini, with species of genera Gaurotes, Acmaeops and Dinoptera.

\section{Material and Methods}

Insects. Two male specimens of Desmocerus palliatus (Desmocerini) were captured in Québec province in July 2005. The other insects studied are generally classified into the tribe Lepturini (Lobl \& Smetana, 2010, Tavakilian \& Chevillote, 2017). They were collected in Greece in May 2018 and in the South of France in June 2018 (table 1). For Stictoleptura hybrida, the eggs of a single female were studied. For other species, 3 to 5 male specimens were dissected.

Cytogenetic techniques. Following anaesthesia by ethyl acetate, mid-gut and testicular follicles were dissected and dropped into an aqueous solution of $0.88 \mathrm{M}$ $\mathrm{KCl}$ (Potassium Chloride) where they remained for $15 \mathrm{~min}$ at room temperature. They were transferred into a micro-centrifuge tube (VWR International SAS, code 211-0033, Strasbourg, France) containing either $0.5 \mathrm{ml}$ of $0.55 \mathrm{M} \mathrm{KCl}$ (hypotonic) solution or diluted foetal calf serum (distilled water 3 vol. and serum 1 vol.), where they were squashed and suspended using a piston pellet (VWR, code 045420) adjusted to the internal diameter of the tube. The volume of the hypotonic solution was completed to $1.5 \mathrm{ml}$. After $10 \mathrm{~min}$, the cell suspension was centrifuged during $5 \mathrm{~min}$ at $800 \mathrm{~g}$. The supernatant was replaced by Carnoy I fixative, in which the cells were suspended and left for at least 30 min. After one change of fixative, the cells were spread on wet and cold slides or conserved for a few days before use. Slides were stained by Giemsa ( $2 \%$ in water) and photographed. They were further C-banded according to Angus (2008).

\section{Results}

\section{Gametogenesis.}

In all adult specimens, but $D$. palliatus, gametogenesis was achieved at the time of capture, and only spermatozoa were found in the tests. In D. palliatus, all the stages of gametogenesis were still present, although this species was captured later in season.

\section{Chromosomes.}


Genus Stictoleptura. The 4 species studied here have quite similar karyotypes, composed of 19 chromosomes in the male, including a single sex chromosome: $19, X$. As in other Lepturini (Dutrillaux \& Dutrillaux, 2018), pair $N^{\circ} 1$ is much larger than the other autosomes, which have a progressively decreasing size (Fig. 1 A-D). All the chromosomes are metacentric or sub-metacentric. As often in Lepturini, it is difficult to obtain a C-banding, which remains faint and often limited to some centromere regions.

Vadonia bisignata. All the chromosomes are metacentric or sub-metacentric, with a size hiatus between chromosome 1 and others. After C-banding, all the centromere regions are stained, but with variable intensities. As for genus Stictoleptura, the $\mathrm{Y}$ is missing: 19,X (Fig.1 E).

Judolia sexmaculata. Its karyotype has the same characteristics as that of species of Stictoleptura and Vadonia: 19,X (Fig. 1 F).

Cortodera humeralis. Its karyotype is quite different from the preceding ones. It is composed of 22 chromosomes, including one minute $\mathrm{Y}$ chromosome: $22, \mathrm{XY}$. There is no size hiatus between pair $\mathrm{N}^{\circ} 1$ and others, and 4 pairs of autosomes are acrocentric (Fig $1 \mathrm{G}$ ).

Desmocerus palliatus. Compared to that of other species, its karyotype is much more difficult to decipher. It is composed of 23 chromosomes, of which 3 of unequal sizes cannot be paired and probably represent neo sex chromosomes (a, b, c). To understand how they are dispatched in gametes, we made karyotypes with brother spermatocytes II composed of 11 and 12 chromosomes. The largest and the smallest neo sex chromosomes ( $\mathbf{a}$ and $\mathbf{c}$ ) were identified in 18/22 spermatocytes II with 12 chromosomes (Fig. 2). They were considered as the neoXs. The medium sized one (b) was identified in 15/17 spermatocytes II with 11 chromosomes. It was considered as the neoY. Pair $\mathrm{N}^{\circ} 1$ is very large, but its larger arm is principally composed of C-banded heterochromatin (Fig.3). Three other autosome pairs are metacentric and the 6 others are acrocentric, with various amounts of $\mathrm{C}$-banded heterochromatin in the centromere region. Many telomeric regions are also C-banded (Fig. 2, 3) In spermatocytes at metaphase I, there are apparently 11 bivalents and one monovalent. However, after prolonged C-band treatment, as after silver staining, the monovalent is more or less loosely, but systematically, linked to the same bivalent by a structure presumably composed of proteins (Fig. 4 A, B). By analogy with beetles with XY sex chromosomes and a parachute sex bivalent $X y p$, this structure is probably of nucleolar origin. Thus, the 
apparent bivalent $\mathbf{a}-\mathbf{b}$ and monovalent $\mathbf{c}$ form an atypical sex trivalent $\mathbf{a}-\mathbf{b}-\mathbf{c}$, in which: $\mathbf{a}$ and $\mathbf{b}$ are linked by one (Fig. 4B) or 2 chiasmata (Fig. 4A) in their long arms composed of autosomal material, and $\mathbf{b}$ and $\mathbf{c}$ are linked by nucleolar proteins. Thus, $\mathbf{a}$ and $\mathbf{c}$ are the neoXs and $\mathbf{b}$ is a the neoY, but it remains difficult to accurately reconstruct the rearrangement which occurred.

\section{Discussion}

The scarcity of the published data on Lepturinae chromosomes, and particularly on the males (Smith, 1953, Ehara, 1956, Teppner, 1968, Dutrillaux \& Dutrillaux, 2018 ) is caused by the high difficulty for obtaining dividing cells. In most species, male gametogenesis ends before the emergence of the imago (Edwards, 1961, Dutrillaux, 2008). This makes necessary to either work on pre-imaginal stages, often difficult to identify, or analyse somatic cells, which have a very low proliferating rate in the imago. It explains the modest quality of the pictures obtained and the quasi-absence of publication on meiotic stages. In rare exceptions however, the gametogenesis period is delayed and persists in the young imago, as in genera Acmaeops, Gaurotes, Grammoptera and Desmocerus (Smith, 1953, Ehara, 1956, Dutrillaux \& Dutrillaux, 2018 and this study). Here, we show that the males of 4 species of the genus Stictoleptura have fairly similar X0 karyotypes, which confirms our previous findings about $Y$ chromosome loss in Lepturini. Three other species from 3 different genera usually classified in Lepturini were also studied: J. sexmaculata, V. punctata and C. humeralis. The $19, X$ karyotype of the 2 former species is similar, or very close to that of Stictoleptura, whereas that of the last one largely differs by the number and morphology of autosomes and the presence of a $\mathrm{Y}$ chromosome. This indicates the proximity of genera Stictoleptura, Vadonia and Judolia and their larger genetic distance from the genus Cortodera. The present results, added to those previously obtained in chromosome studies of Lepturinae, are summarized in Table 2. It shows the clear separation of studied Lepturini from other Lepturinae, in relation with their low chromosome numbers, following the loss of their $Y$ chromosome. At difference, 3 chromosome profiles are found in the species of Rhagiini that we studied: that of the genus Rhagium, that of the group $A$. pratensis, $C$. humeralis, $D$. collaris, $G$. virginea and $G$. ruficornis and that of other species.

The position of Cortodera humeralis. Interestingly, the karyotype of $C$. humeralis is very similar to that of some species classified in Rhagiini: Acmaeops pratensis, Gaurotes virginea and Dinoptera collaris (Dutrillaux \& Dutrillaux, 2018). In the past, the genus Cortodera has been alternatively classified in Lepturini or Rhagiini, 
but recent classifications rather favour its position in Lepturini. A molecular phylogeny however, based on $\mathrm{CO} 1$ gene sequencing, proposed its classification in Rhagiini, close to $A$. pratensis, G. virginea and D. collaris (Sykorova, 2008). These data, fully compatible with the chromosome data, provide independent and strong arguments to bring genus Cortodera into Rhagiini rather than Lepturini. More precisely, the four genera Acmaeops, Cortodera, Dinoptera and Gaurotes constitute a monophyletic group, which was differentiated from other Rhagiini by at least one rearrangement of chromosomes, which increased their number to $2 \mathrm{n}$ $=22$. We also mentioned that male gametogenesis is delayed until the imago stage in this group, but this could not yet be confirmed for the males of $C$. humeralis.

The position of Grammoptera ruficornis. As Cortodera, genus Grammoptera was alternatively classified in Lepturini or Rhagiini, with a preference for Lepturini in recent classifications (Tronquet, 2014). This is in agreement with the CO1 sequence data, which place Grammoptera amongst Lepturini (Sykorova, 2008). Obviously, this does not fit with our chromosome data. This species has 24 chromosomes, including a Y chromosome, which is lost by all (22/22) "other" Lepturini that we studied. The presence or absence of the $Y$ chromosome probably has no incidence on the phenotype and thus on the morphological characters used for classifications. However, it seems to have a great importance for the mode migration of chromosome $X$ at anaphase $I$ of meiosis. The lack of $Y$ prevents the formation of the parachute structure, in which the $X$ and $Y$ are associated through nucleolar proteins, present in all XY males of Coleoptera (Smith and Virkki, 1978). This requires other relationships between the $X$ and nucleolar proteins (Dutrillaux \& Dutrillaux, 2017). Furthermore, the loss of $Y$ is not reversible, at difference with gene mutations and chromosome rearrangements. Thus, several hypotheses might explain the presence of a $\mathrm{Y}$ chromosome in the karyotype of $G$. ruficornis:

1- The genus Grammoptera has been misclassified in Lepturini.

2- Its lineage was isolated very early during Lepturini evolution, before the loss of the $Y$, which involved all other lepturini studied so far.

3- Its ancestors followed a typical Lepturini evolution, with $Y$ chromosome loss, but this chromosome was later re-introduced by the hybridization of a female (which would fit with data on mitochondrial CO1) with a XY male from another tribe. 
This last interpretation is attractive, but the number of chromosomes, above 20, and the size reduction of chromosome 1 bring the karyotype G.ruficornis close to that of the group Acmaeodera, Dinoptera, Gaurotes and Cortodera, thus amongst Rhagiini. Obviously, sequence comparisons of nuclear DNA are needed to propose definitive conclusions.

Presence of a monophyletic group amongst Rhagiini. There is some variability in the karyotypes of Rhagiini, but many species share a 20,XY male karyotype. It is principally composed of non-acrocentric chromosomes, as in most other species of Cerambycidae, and is assumed to be close to the karyotype of polyphagan ancestors (Dutrillaux \& Dutrillaux, 2009). Amongst Rhagiini, the group of species from genera Acmaeops, Cortodera, Dinoptera, Gaurotes and Grammoptera is clearly individualized by its higher chromosome number (22-24) and the distribution of chromosome sizes. This indicates that at least one chromosome rearrangement, possibly a fission, occurred in a common ancestor, separating them from other Rhagiini. Interestingly, gametogenesis, which ends at the preimaginal stage in other Lepturinae (Edwards, 1961, Ehara, 1956), is prolonged in the young imago in species of this group. Considering these characters, we propose that these genera form a monophyletic group derived from Rhagiini ancestors.

The position of Desmocerus palliatus. Surprizingly, in cladograms proposed by Sykorova (2008), D. palliatus was placed into "Lepturini", near genera Grammoptera, Etorofus and Eustrangalia. The complex karyotype of this species is very different from that of other Lepturinae, but its interpretation may be misleading. It has an odd number of chromosomes $(2 n=23)$, no minute $Y$ chromosome and a chromosome 1 much larger than the others. These criteria could bring it close to Lepturini, but a more precise analysis discards this possibility. The large size of chromosome 1 is the consequence of C-banded heterochromatin amplification, whereas the large chromosome 1 of Lepturini is composed of euchromatin: thus, their origins are different. The odd number of chromosomes is the consequence of a complex gonosome-autosome translocation, which leads to a chain trivalent at metaphase I of meiosis. Nucleolar proteins are included in this trivalent. Such a link between the $X$ and $Y$ through nucleolus at metaphase $I$ is known only in the parachute structure $\left(X y_{p}\right)$ present in most species of Coleoptera, including Rhagiini but not Lepturini. Finally, many autosomes are acrocentric (Table 2), whereas all or almost all autosomes are metacentric in Lepturini. Thus, the originality of the karyotype of $D$. palliatus is 
compatible with its position in a separate tribe, the Desmocerini, (Bouchard et al., 2011, Tavakilian and Chevillote, 2017), but certainly not in Lepturini. Its number of chromosomes, above 20, and its late gametogenesis may link $D$. palliatus to the group of Rhagiini (Acmaeops, Gaurotes, Dinoptera and Grammoptera) with 22-24 chromosomes, but this may a convergence. We could not precisely reconstruct the rearrangement, which originated its 3 neo-sex chromosomes. In all the species of Coleoptera with a gonosome-autotome translocation, the ancestral $\mathrm{Y}$ is probably lost and the 2 neo-sex chromosomes are not linked by nucleolar proteins at metaphase I, but by a chiasma, which occur in their autosomal component (Dutrillaux \& Dutrillaux, 2009 and additional personal data). In D. palliatus, 2 of the 3 derivative chromosomes are linked by nucleolar material, which suggests that the sites of linkage with the nucleolus of both ancestral chromosomes $X$ and $Y$ are maintained. This system, which is similar or close to that described in a Scolytid and some Chrysomelids (Smith and Virrky, 1978), remains a rare form of autosome-gonosome translocation in beetles.

In conclusion, this study increases to 13 the number of genera and 23 the number of species of Lepturini studied with a 19,X karyotype, which supports a little more the hypothesis that the loss of chromosome $Y$ is a synapomorphy of this tribe. The $22, \mathrm{XY}$ karyotype of $C$. humeralis discards its position in Lepturini, but brings it close to a group of Rhagiini, composed of genera Acmaeops, Gaurotes and Dinoptera, which share other similar chromosomal characters. In addition, the $24, \mathrm{XY}$ karyotype of $\mathrm{G}$. ruficornis is probably derived, but close to this $22, \mathrm{XY}$ karyotype. Thus, we propose that genera Acmaeops, Gaurotes, Cortodera, Dinoptera, Grammoptera form a monophylic group, well separated from other Rhagiini by their chromosome constitution. Finally, it is shown that the karyotype of $D$. palliatus is characterized by the presence of a rare form of autosomegonosome translocation.

\section{References}

Angus RB. 2008. Further karyosystemetic investigation of the Stictotarsus griseostriatus (De Geer) group of sibling species (Coleoptera: Dytiscidae). Comparative Cytogenetic 2: 151-156.

Bouchard $\mathrm{P}$, Bousquet $\mathrm{Y}$, Davies AE, Alonso-Zarazaga MA, Lawrence JF, Lyal CHC, Newton AF, Reid CAM, Schmitt M, Ślipiński SA, Smith ABT 2011. Familygroup names in Coleoptera (Insecta) ZooKeys 88: 1-972. 
Dutrillaux B. 2008. A propos des variations de coloration, liées au sexe (hétérochromatisme sexuel) ou non (polychromatisme), chez les Cerambycidae de la faune de France (Coleoptera). Bulletin de la Société entomologique de France 113: $155-172$.

Dutrillaux A-M, Dutrillaux B. 2009. Sex chromosome rearrangements in Polyphaga beetles. Sexual Development. 3: 43-54.

Dutrillaux A-M, Dutrillaux B. 2017. Evolution of the sex chromosomes in beetles Dutrillaux B. 2017..I. The loss of the Y chromosome. Cytogenetic and Genome Research. 152: 97-104.

Dutrillaux A-M ,Dutrillaux B. 2018. Loss of Y chromosome may be a synapomorphy of the tribe Lepturini (Coleoptera: Cerambycidae: Lepturinae). European Journal of Entomology. 115:45-52.

Dutrillaux A-M, Pluot-Sigwalt D, Dutrillaux B. 2010. (Ovo-) viviparity in the darkling beetle, Alegoria castelnaui (Tenebrionidae: Ulomini), from Guadeloupe. European Journal of Entomology 107: 481-485.

Edwards JS. 1961. On the reproduction of Prionoplus reticularis (Coleoptera, Cerambycidae), with general remarks on reproduction in Cerambycidae. Quaterly Journal of Microscopical Science 102: 519-529.

Ehara S. 1956. A comparative histology of male gonads in some cerambycid beetles with notes on the chromosomes. Journal of the Faculty of Sciences of Hokkaido University (Ser.VI Zool.) 12: 309-316, pl. XII.

Lobl I, Smetana A. 2010. Catalog of Palaearctic Coleoptera. Vol. 6. Chrysomeloidea. Apollo, Stenstrup. 924p.

Smith SG. 1953. Chromosome numbers in Coleoptera Heredity 7: 31-48.

Smith SG ,Virkki N. 1978. Animal Cytogenetics,vol 3: Insecta 5: Coleoptera (Gebrüder Borntraeger, Berlin-Stutgart. 366p.

Sykorova M. 2008: Molecular Phylogeny of Subfamilies Spondylinae and Lepturinae (Coleoptera: Cerambycidae) Based on Mitochondrial 16S RNA. B.Sc. Thesis, University of South Bohemia, České Budějovice, iv + 34 pp. [in Czech].

Tavakilian, G.L. \& H. Chevillotte. 2017. Titan: base de données internationales sur les Cerambycidae ou Longicornes. Version 3.0. Available from: http:/titan.gbif.fr/ 
Teppner H. 1968. Chromosomenzahlen einiger mitteleuropäischer Cerambycidae (Coleoptera). II Chromosoma (Berlin) 25 : 141-151.

Tronquet M. 2014. Catalogue des Coléoptères de France. Revue de l'Association Roussillonnaise d'Entomologie, 23 (Supplément): 1-1052.

\section{Legendes}

Table 1 List of species studied with their current tribe position (L: Lepturini; D: Desmocerini), locations of capture and tissues which provided us with proliferating cells.

Table 2 Summary of data on chromosome number and morphology from 38 species of Lepturinae reported in Dutrillaux \& Dutrillaux (2018) and this study. 2n $=$ diploid chromosome number in the male; ND: only female studied (20,XX); Y+ or -: presence or absence of the Y; X: Morphology of the X: SM: Sub-Metacentric, M: Metacentric, A: Acrocentric; 1 > 2: size hiatus between chromosomes 1 and 2; 1,2 >3: size hiatus between chromosomes 2 and $3 ; 1 \cong 2 \cong 3$ : no size hiatus between chromosomes 1, 2 and 3; NA: number of acrocentric autosomes and in the bracket, $\mathrm{N}^{\circ}$ of the autosome(s) involved. Hetero: presence of large fragments of heterochromatin; neo: neochromosome.

Figure 1 Giemsa stained karyotypes of A) S. cordigera, B) S. fulva, C) S. hybrida, D) S. pallens, E) V. bisignata, F) J. sexmaculata, G) C. humeralis.

Figure 2 Spermatocytes II of D. palliatus. Top: karyotype made with 2 brother spermatocytes. Each chromosome is shown twice, after Giemsa staining (center) and C-banding (right and left). The chromosomes from the 12,neoXa neoXc spermatocyte are placed on the left and those of the $11, \mathrm{Yb}$ spermatocyte are placed on the right. Bottom: the 2 spermatocytes II (A and B) used for establishing the karyotype.

Figure 3 C-banded karyotype of a spermatogonium of $D$. palliatus, exhibiting the 3 neo sex chromosomes $(\mathbf{a}, \mathbf{b}, \mathbf{c})$. Inset: Pair $\mathrm{N}^{\circ} 1$ from another cell, submitted to a prolonged C-banding, which demonstrates the heterochromatic (h) constitution (containing repeated DNA) of its long arms.

Figure 4 Diakineses/metaphases I of D. palliatus after Giemsa staining (left) and C-banding (right). The apparent monovalent $\mathbf{c}$ and bivalent $\mathbf{a}$-b (left) are 
in fact linked and form an atypical neosex trivalent a-b-c (right).

Chromosomes $\mathbf{a}$ and $\mathbf{b}$ are linked by a single terminal chiasma in A (top) or 2 chiasmata in B (bottom, less frequent configuration). Bivalent 1 exhibits a single chiasma in its euchromatic portion in A and 2 terminal chiasmata (ring) in $\mathrm{B}$. Bar $=10 \mu \mathrm{m}$ 